\title{
Christianity and politics
}

$\mathrm{T}$ his special issue of Approaching Religion deals with questions concerning the multi-faceted relationship between religion and politics. The issue is based on an interdisciplinary conference 'Christianity and Politics', organised at the University of Turku, Finland, in November 2018. The conference focused on Christianity with critical attention to the examination of the relationship between Christianity and politics in the West. Of the large variety of topics examined at the conference, this special issue includes a selection of four articles addressing the different ways in which religious organisations attempt to make an impact on state authorities or leading political parties' politics, and vice versa. Elina Hartikainen focuses on the negotiation of the role of religious expert knowledge in secular state processes in Finland; Gašper Mithans examines the fascist oppression of Protestant minorities in an area that currently is part of Italy; Marja Vuorinen concentrates on the appropriation of religion in neo-nationalist ideologies in Europe; and Anastasia Mitrofanova scrutinizes Orthodox attempts to affect equality laws and policies in Moldova. In addition, the special issue includes book reviews authored by Tuomas Äystö and Kati Rissanen.
The relationship between religion and politics is extremely complex and delicate. Over time the boundaries between the two have been drawn in various ways. Religion is often understood as a clearly bounded phenomenon affecting politics either directly or indirectly. However, religion is also approached as something that can be used as a political tool. Both approaches tend to simplify the complex relationship between religion and politics. 'Religion' and 'politics' are not bounded phenomena and they should not be seen as existing as such in the world. Whereas politics may refer to public decision-making processes that are easily recognised as something we call politics, it may equally refer to the sphere of the private and ordinary. Likewise, the term religion designates not only religious action related to churches and religious institutions, but is also something flexible and fluid that easily evades attempts to define it. Various phenomena may therefore be termed political and religious and they should only be named and categorised as such in particular contexts.

In the present issue the interrelatedness and the delineation of the spheres of Christianity and politics are discussed in four case studies. In her article, Elina Hartikainen asks, how, if at all, religious 
expert knowledge counts in a secular state context. She explores this topic through religious media representations of, and attempts to impact on, the general attitude toward the issue of evaluations of asylum seekers' conversions in Finland. In 2017 , for example, about one thousand asylum applications employing as justification the applicant's conversion from Islam to Christianity were submitted to the Finnish Immigration Service (Migri). The decisions made concerning these applications received much public attention. Especially in regard to negative decisions, Migri's competence as a secular organisation to make decisions about religious conversions was questioned. Hartikainen examines writings in one Christian newspaper, Kirkko ja kaupunki ('Church and City'), between 2015 and 2018 to scrutinize how the level of engagement of religious expertise in relationship to Finnish immigration authorities and the validity and objectivity of religious authorities' knowledge in regard to the question of asylum seeking was negotiated in and through the texts published. Hartikainen shows how in the writings the Evangelical Lutheran church officials' knowledge of faith and religion was considered equally legitimate and objective as secular expert knowledge, and how Migri was presented as denying the objectivity of religious expertise. According to Hartikainen, these writings reveal how what counts as objective knowledge in a state context is determined not only by certain general criteria of objectivity but also the experts' institutional background and positioning in relationship to the state. Religious experts' knowledge does not appear to be equally objective as secular experts' knowledge. On the other hand, religious expertise cannot be totally discounted either. Therefore, the negotiation concerning objectivity between the secular state and institutionalised religion proves to be ongoing; the relationship between the two cannot be fixed.

Gašper Mithans places his article in a complex religious-ethnic context of a geographical area which after the first World War was incorporated into Italy having previously belonged to the Habsburg monarchy. The new Italian fascist regime implemented an oppressive state policy against minorities, the major groups of which were various Protestant movements. The collaboration with the Catholic Church was possible as these two institutions shared similar interests. Mithans' case study, based on the regional and diocesan archival sources from the area of the Julian March offers an insight into religious minorities of that border area and at the same time it opens a broader view onto the fascist regime covering the interwar period. The scrutiny reveals differences in the implementation of surveillance, intimidation and actual persecution of the Protestant groups by the fascist authorities with regard to time and place. The analysis makes visible the inevitable: the border area fascism put more hostile measures into operation against the Protestants when Italy entered into the war. However, both the border area fascism and the Catholic Church were more tolerant towards those Protestant groups which did not proselytize outside their communities than those which did, among them Adventists and Pentecostals. The interventions of the Italian fascist regime against religious minorities were usually based on their suspicious activities and ethnic compositions: the existence of multi-cultural and multi-national communities in the border area provided a rationale for strong oppressive measures.

In her article Marja Vuorinen scrutinizes the role of different religions in the composition of the ideological programmes of the 
Northern European far right in the 2010s. Neo-nationalist ideologies utilise European - 'native' - religions, from high church Catholic Christianity to pagan cults and local folklore. The main perceived adversary for these far-right ideologies is Islam. Vuorinen maps the history of nationalist ideologies in Europe and shows that there is a continuum that expands over two hundred years, starting from separatist movements opposing the supremacy of imperial multi-ethnic empires and ending in the clash between Christianity and Islam - 'the two great Manicheans', as Vuorinen phrases it. Vuorinen analyses permanent foundational texts, that is to say writings, manifestos and other publicly available materials produced and published by well-known farright figures. She utilises methodological empathy in order to take the ideological message of the group seriously, but still analysing it in its specific temporal and situational context. This process reveals why certain ideologies are supported, by whom and to what end. Vuorinen states that the materials embody an array that might be called 'neo-tendencies', that is neo-nationalist, neo-conservative, neo-romantic, neocollective, neo-masculine, but also neospiritual and neo-religious. Religious as well as nationalist tendencies are connected to the idea of emotional community, that provides a feeling of being part of something larger than yourself. Vuorinen ends with an argument for further consideration of the topic. These exclusive and aggressive expressions of radical neo-nationalists could be perceived also as symptoms of social friction that can result in violent societal conflicts. The rise of established and recognised neo-conservative and neonationalist parliamentary parties may act as a pressure reducing valve.

In her contribution, Anastasia Mitrofanova discusses religious organisations' ways of impacting state legislation. She examines the strategies of two different Orthodox Churches in opposing equal opportunities legislation in Moldova, which is going through processes of Europeanization and post-socialist transformation. The two churches under scrutiny both have their own approach to the issue of equal opportunities such as LGBT rights. The Moldovan Orthodox Church initially relied on private bargaining with the government but later on had to change to direct action in opposing the Law on Ensuring Equality. On the other hand a section of the Church, the radicals, utilise direct political activist strategies to fight forces favourable to homosexuality. They also criticise the Moldovan Orthodox Church for being too liberal. The Bessarabian Metropolitanate of the Romanian Orthodox Church employs less radical means, focusing on systematic social and youth work through which they attempt to have societal impact. Mitrofanova analyses the success of these strategies to attract followers to the Churches through the theoretical framework of religious markets. She shows how the transition from a regulated religious market to freer religious competition in Moldova has created a situation in which the Orthodox Churches have had to rethink their social strategies for fear of losing followers to Protestant churches, for example. However, the new more liberal social discourse, especially on the topic of LGBT rights, has given the Orthodox actors a renewed opportunity to reach out to the wider society. Mitrofanova argues that in that in this endeavour the Metropolitanate of Moldova has thus far been the most successful. Nevertheless, the author concludes that its success is unlikely to continue in the future if it does not find a way to keep up with the societal changes it simultaneously opposes. 
These articles demonstrate the sensitive relationship between religion and politics in a variety of cultural environments and situations dating from the early twentieth century to the present day. An especially accentuated feature of these four case studies is the subordinate position of religion/ faith to politics. A political (Hartikainen, Mithans, Vuorinen), but also religious (Mitrofanova) "elite", that is to say, a group which has the requisite power, aims to assert control over the definitions of correct religious practice. In these cases religion appears to be a strong identity-marker, and as such it offers to the elite or authorities tools for effecting group inclusion and exclusion, or deportation, and in extreme situations, persecution.

As seen in all of the articles presented above, it can be stated that questions concerning the relationship between religion (in this case Christianity) and politics unveil complex interactions where these spheres (i.e. religion and politics) do not work as tightly delineated counterparts acting on each other, but form a field where the boundaries between religion and politics are softened. It is more or less question of prolific and unexpected encounters resulting in a variety of actions aspiring to exert influence. When dealing with politics and religion - both being related to problematics of power - a critical approach is of the utmost importance. The Christianity and Politics Conference, as well as this special issue, constitute small steps towards a deeper understanding of this field.

\section{Anna Haapalainen, Minna Opas and Marika Räsänen} Guest editors
Anna Haapalainen is doctoral candidate at the Department of Study of Religion. They are also Secretary and board member of the Centre for the Study of Christian Cultures. Haapalainen was the coordinator and member of organizing committee of the Christianity and Politics conference.

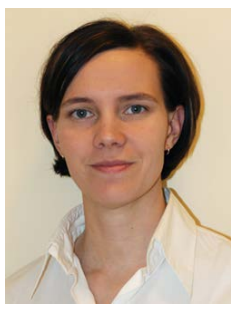

Minna Opas is University Teacher in Study of Religion and Docent of Anthropology of Religion at the University of Turku. She is the director of the Centre for the Study of Christian Cultures. She was member of the organizing committee of the Christianity and Politics conference.

Marika Räsänen currently holds the position of University Lecturer in Cultural History at the University of Turku. She is the vicedirector of the Centre for the Study of Christian Cultures. She was member of the organizing committee of the Christianity and Politics conference.

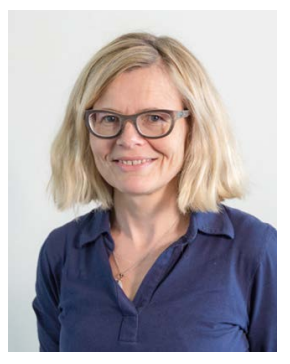

